\title{
Educating Oregon Families about Child Safety Seats
}

\author{
Frances Biagioli \\ Oregon Health \& Science University, Department of Family Medicine
}

\begin{abstract}
Child safety seats are being used more frequently, but correct and consistent use is still a problem. Educating the community and medical professionals about the correct use of child safety seats helps with correct usage. Educational campaigns can be directed to parents, medical professionals, safety professionals (fire and police departments), hospitals, and schools. Television public service announcements, mailings, billboards, radio spots, and a web site have all been part of a successful child safety seat educational campaign in Oregon. Improving the public's knowledge of the correct use of child safety seats will reduce the number of childhood injuries, and medical professionals can play a significant part in this educational campaign.
\end{abstract}

(C) 2004 Californian Journal of Health Promotion. All rights reserved.

Keywords: Infant Equipment, Protective Devices, Child, Preschool, Safety, Automobiles

\section{Introduction}

Automotive injury is the leading cause of death for children ages 1 year to 14 years (WISQARS 1999-2001). Child safety seats substantially reduce the chance for injury and death. They are 71 percent effective in reducing fatalities among infants and 54 percent effective for toddlers (NHTSA 9/2004). Booster seats reduce the chance for injury in children 4 to 8 years old by 59 percent (Winston 2003).

Despite the clear benefit, an alarming number of children are riding in automobiles without appropriate restraints or the restraints are used incorrectly. In 2002, 5,527 children less than 80 pounds in six states were studied. Sixty-two percent were in a child safety seat, 26 percent were in a vehicle adult seatbelt, and 12 percent were unrestrained. Of those restrained, 72.6 percent were found to be incorrectly restrained (NHTSA, 2004). Parents need to know the benefits of child safety seats; they need to know which seat would be safest for their child; and they need be educated in the seat's proper use.

\section{Educating the Public About Child Safety Seats}

Although child safety seat use has improved, more education is needed. Educational campaigns in Oregon have included television public safety announcements, radio spots, newspaper advertisement and articles, billboard messages, mailings, flyers, and a web site. The Oregon Department of Transportation and the Oregon Health Division fund these educational efforts; in addition, they are major sponsors of the National Child Passenger Safety Week campaign, which occurs in mid-February.

The child safety seat educational campaigns in Oregon have directly affected correct usage. For example, in January 1, 2002 Oregon's booster seat law was implemented. This law requires all children who are less than 6 years of age or sixty pounds to be restrained appropriately with a booster seat. In 2002, six months after the law was implemented Oregon booster seat use was documented at $29 \%$. After a multi-media state wide booster seat educational campaign a $44 \%$ booster seat usage rate was noted in 2004 . (ODOT 2004) It is important to implement an educational campaign that includes ways to sustain the message after the campaign is over. The state of Oregon created a resource center to sustain the message about child passenger safety issues. 
Under the direction of the Oregon Department of Transportation, the Alliance for Community Traffic Safety in Oregon (ACTS Oregon) was established as a 501 (c) (3) non-profit in 1995. The ACTS Oregon mission is to reduce the number of fatalities and the severity of injuries from vehicle crashes in Oregon; to accomplish this it provides resources, technical training, and education. One of their programs is the Child Safety Seat Resource Center (CSSRC).

The CSSRC acts as a clearinghouse for educational resources for the community regarding proper use of child safety seats. Its website (http://www.childsafetyseat.org) provides free access to downloadable educational brochures about correct child seat use in *.pdf format (see Table 1 for URLs). The CSSRC provides technical training as well as sponsors the National Standardized Child Passenger Safety Training course to certify child passenger safety advocates as technicians providing child safety seat installation and inspection. The center helps these volunteers to teach the communities across the state about child safety seats. The majority of this education occurs at child safety seat check up events where Certified Child Passenger Safety Technicians teach parents to correctly use and install seats into their vehicles. Child safety seat checkup events are listed on a calendar on the CSSRC's web site. Limited grant funds are available to assist with checkup events. In addition, the CSSRC coordinates a child safety seat distribution program with partners in counties throughout Oregon. These seats are provided at a reduced cost to needy families. The CSSRC provides education through its flyers as mentioned above; on its website it provides essential web links; and the center fields questions from the public and directs parents to their nearest child safety seat check up event or technician through its toll-free number.

Table 1

List of Available Flyers

\begin{tabular}{|l|l|}
\hline \multicolumn{1}{|c|}{ Flyer Name } & \multicolumn{1}{c|}{ URL } \\
\hline $\begin{array}{l}\text { Booster Seats: Position Children for } \\
\text { Safe Travel }\end{array}$ & http://www.actsoregon.org/csr/pdf/booster.pdf \\
\hline $\begin{array}{l}\text { They’re Growing Up But They're } \\
\text { Not Grown-ups. (English) }\end{array}$ & http://www.actsoregon.org/csr/pdf/English_wboostr.pdf \\
\hline $\begin{array}{l}\text { They're Growing Up But They're } \\
\text { Not Grown-ups. (Spanish) }\end{array}$ & http://www.actsoregon.org/csr/pdf/Spanish_wboy.pdf \\
\hline $\begin{array}{l}\text { Kids Don’t Come With Instructions } \\
\text { (Fortunately, their safety seats do). } \\
\text { (English) }\end{array}$ & http://www.actsoregon.org/csr/pdf/English_wtoddler.pdf \\
\hline $\begin{array}{l}\text { Kids Don’t Come With Instructions } \\
\text { (Fortunately, their safety seats do). } \\
\text { (Spanish) }\end{array}$ & http://www.actsoregon.org/csr/pdf/Spanish_wtoddler.pdf \\
\hline $\begin{array}{l}\text { Give Your Infant Seat A Check Up. } \\
\text { (English) }\end{array}$ & http://www.actsoregon.org/csr/pdf/English_winfant.pdf \\
\hline $\begin{array}{l}\text { Give Your Infant Seat A Check Up. } \\
\text { (Spanish) }\end{array}$ & http://www.actsoregon.org/csr/pdf/Spanish_winfant.pdf \\
\hline
\end{tabular}

\section{Educating Medical Professionals about Child Safety Seats}

Health professionals provide information to parents daily about many health-related topics. If health professionals are educated about the correct use and selection of child safety seats, they can be a reliable and sustainable resource for this information in the future. With this in mind, the CSSRC offers its advice to Oregon health professionals with child safety seat 
questions by phone or through its web site. In addition, the CSSRC partners with the Oregon Medical Association to educate medical professionals during National Child Passenger Safety Awareness Week (this year: February 13 through 19, 2005). Funded in part by the Oregon Department of Transportation, the Oregon Health Division, and the Oregon Medical Association, CSSRC sends a mailing to health professionals who interact with children and parents. This mailing includes a child passenger safety fact sheet, a set of child safety seat educational flyers, and a donation form for child seat vouchers. The fact sheet highlights pertinent child safety seat usage facts pertinent to the state and implores health providers to educate their patients about the problem. Educational flyers are included in the mailing, and the health professionals can copy them for their patients, order more through the resource center, or download them from the website. The donations for the voucher program help provide child seats to low-income families for low or no price.

Medical professionals can also learn about child safety seats from resources available on the internet and in journal publications. The National Highway Transportation Safety Administration's web site has extensive information about Child Passenger Safety (http://www.nhtsa.dot.gov/CPS/) and it rates child safety seats on their ease of use (http://www.nhtsa.dot.gov/CPS/CSSRating/Inde x.cfm). The American Academy of Pediatrics publishes its yearly update of "Car Safety Seats: A Guide for Families" (available at: http://www.aap.org/family/carseatguide.htm).

This guide gives instructions on correct child safety seat selection and use; it lists safety seats, their weight limits, and their approximate cost; it has a link to check for recalls; and it lists all the child safety seat manufacturers' contact information. Other sources for education include journal articles that have been published on the subject (AAP, 2002; Biagioli 2002; Bull \& Sheese, 2000; Winston, Durbin, Kallan, Moll, 2000).

\section{Conclusion}

Educational efforts regarding child safety seats in Oregon have shown promise. Seat use is improving, but many parents are still using the seats incorrectly, not using them long enough, and some are not using seats at all. Educational campaigns can affect the correct use of child safety seats and medical professionals can be instrumental in getting the message to parents.

\section{References}

American Academy of Pediatrics. (2002). American Academy of Pediatrics. Committee on injury and poison prevention. Selecting and using the most appropriate car safety seats for growing children: Guidelines for counseling parents. Pediatrics, 109, 550-553.

Bull, M. J., Sheese, J. (2000). Update for the pediatrician on child passenger safety: Five principles for safer travel. Pediatrics, 106, 1113-1116

Biagioli, F. E. (2002). Proper use of child safety seats. American Family Physician, 65, 2085-2090.

Oregon Department of Transportation. (2004). Oregon Department of Transportation, Transportation Safety Division. Oregon Occupant Protection Observation Study, Intercept Research Corporation, September 2004.

United States Department of Transportation, National Highway Traffic Safety Administration. (January 2004). Misuse of child restraints. Technical report. DOT HS 809 671. Retrieved January 2004, from http://www.nhtsa.dot.gov/people/injury/research/Misuse/index.html

United States Department of Transportation. National Highway Traffic Safety Administration. (September 2004). Motor vehicle occupant protection facts - Children, Youth, and Young Adults. Retrieved October 2004, from http://www.nhtsa.dot.gov/people/injury/airbags/OccupantProtectionFacts/index.htm

Winston, F. K. (June 4, 2003). Journal of the American Medical Association. Partners for Child Passenger Safety (PCPS), The Children's Hospital of Philadelphia. 
Winston, F. K., Durbin, D. R., Kallan, M. J., Moll, E. K. (2000). The danger of premature graduation to seat belts for young children. Pediatrics. 105, 1179-1183

WISQARS. (2004). Leading causes of death 1999-2001. Atlanta GA: Centers for Disease Control and Prevention. National Center for injury prevention and Control. Retrieved October 2004, from http://webappa.cdc.gov/sasweb/ncipc/leadcaus10.html

\author{
Author Information \\ Frances Biagioli, M.D. \\ Assistant Professor \\ OHSU Department of Family Medicine \\ Oregon Health \& Science University
}

